\title{
O rolê feminista: autonomia e política prefigurativa no campo feminista contemporâneo*
}

\author{
Íris Nery do Carmo**
}

Resumo

Este artigo parte do contexto dos movimentos sociais contemporâneos e tem como objeto empírico uma rede informal de ativistas jovens auto-referenciada como rolê feminista, cujas relações são norteadas por ideário associado à autonomia, ao faça você mesma e à horizontalidade. Tendo em vista as formas recentes de politização do gênero e da sexualidade, o artigo busca explorar os sentidos nativos atribuídos à autonomia. Assim, olhando para os discursos e práticas ativistas, discuto a sua materialização na prática da okupação e seus desdobramentos como o escracho - no espaço público. Para tal, dialogo criticamente com a noção de "prefiguração", apontando, à luz dos dados etnográficos, potencialidades e lacunas. Por fim, chamo atenção para a rentabilidade analítica de rolê frente aos limites da categoria movimento social no período pós-anos 2000.

Palauras-chave: Movimentos Sociais, Prefiguração, Feminismos, Autonomia, Escracho.

* Recebido em 13 de abril de 2018, aceito em 21 de novembro de 2018. Este artigo apresenta um recorte de pesquisa mais ampla, que tratou de investigar a produção de sujeitos políticos a partir do rolê feminista em grandes capitais brasileira (Carmo, 2018). A investigação foi desenvolvida no âmbito do Programa de Doutorado em Ciências Sociais da Universidade Estadual de Campinas (Unicamp), sob a orientação da Profa. Dra. Regina Facchini e contou com bolsas fornecidas pelo Conselho Nacional de Desenvolvimento Científico e Tecnológico $(\mathrm{CNPq})$ e pela Fundação de Amparo à Pesquisa do Estado de São Paulo (FAPESP).

** Doutoranda em Ciências Sociais pela Universidade Estadual de Campinas (Unicamp), Campinas, SP, Brasil. irisndocarmo@gmail.com /

https://orcid.org/0000-0001-9736-0034

http://dx.doi.org/10.1590/18094449201900570004

(cc) EY-NC 
The "Role Feminista": Autonomy and Prefigurative Politics in Contemporary Feminist Field

\begin{abstract}
This paper concerns the context of contemporary social movements, by analyzing a young informal activist network called "rolê feminista" which takes autonomy, do it yourself and horizontality as its political orientation. Considering current forms of politicization of gender and sexuality, it aims to explore the native meanings attributed to the category of autonomy. Then, this paper examines the materialization of autonomy in the so called okupação and its contentious unfoldings in the public space. In doing so, it critically discusses the literature on prefigurative politics, pointing out its potentiality and limitations. At last, I highlight the analytical rentability of role towards the limits of social movements category in the 2000s.
\end{abstract}

Keywords: Social Movements, Prefiguration, Feminisms, Autonomy, Escrache. 
Termos como autonomia e horizontalidade têm se mostrado recorrentes quando abordadas as mobilizações recentes protagonizadas por jovens no Brasil. Refiro-me especialmente ao período pós-2010, que assistiu a eventos como as Marchas das Vadias (com início em 2011), as Jornadas de Junho (2013), as ocupações promovidas por estudantes secundaristas (entre os anos de 2015-2016), os atos de rua aglutinados sob o termo Primavera Feminista (2015), as exibições públicas da tática Black Bloc desde 2013, entre outras movimentações que têm ganhado visibilidade especialmente nas grandes capitais do país.

Em especial, nos feminismos latino-americanos o termo autonomia é cíclico e carrega uma trajetória polissêmica. Ele foi evocado outrora por feministas no Brasil durante o regime militar, a fim de demarcar uma posição exterior a partidos políticos $e$ organizações revolucionárias de esquerda (Alvarez, 2014a; Matos, 2014). Seus usos remetem também aos anos 1990, quando a autonomia emerge mais uma vez no campo, sendo polarizada à categoria acusatória "feministas institucionais" (Alvarez, 2014a; Matos, 2014).

A partir dos anos 2000, notam-se transformações nas condições que modulam formatos participativos institucionalizados. Se com a transição democrática o feminismo dos anos 1980 e 1990 teve uma forte articulação com instituições políticas e Organizações Não Governamentais, buscando assim influenciar políticas públicas ao fazer uso de canais socioestatais, no fim da década de noventa começa a tomar corpo o que autoras chamam de "fuga de investimentos" das instituições internacionais (Alvarez, 2014; Gonçalves, Freitas, Oliveira, 2013; Thayer, 2017). Nessa conjuntura, a crítica à centralidade da atuação institucional, entre outros fatores, tem impulsionado alterações nos regimes de visibilidade dos feminismos no país (Facchini; Sivori, 2017) e afetado a produção de sentidos acerca do fazer político. Assim, a autonomia tem sido reivindicada por setores que, organizados em coletivos, rejeitam lideranças formais e se apresentam como horizontais. 
Este artigo parte desse contexto e tem como objeto empírico uma rede informal de ativistas jovens autonomeada como rolê feminista, ou abreviadamente rolê. Elas têm idades entre vinte e trinta anos, muitas estão em trajetórias universitárias, são em grande parte provindas de camadas médias urbanas, e se articulam interligando diversos estados do Brasil, com certa preponderância do Sudeste. ${ }^{1}$

As ativistas que circulam através do rolê reivindicam a autonomia e a horizontalidade em contraposição a formatos organizativos e modos decisórios tidos como autoritários (Carmo, 2018b). Tal reivindicação por vezes produz conflitos com outras atoras do campo feminista, dadas as expectativas e experiências geracionais distintas com relação ao Estado, aos canais de participação socioestatal $e$ atores institucionais ou partidários. Mobilizadas pela politização do cotidiano, elas se apropriam, contestam e ressignificam referências como o anarquismo, $\mathrm{o}$ vegetarianismo e o veganismo, o punk, o direito à cidade, os fanzines, o anticapitalismo, tecendo interlocuções e articulações com outros movimentos e atores sociais - daí a sua presença em menor ou maior escala nas mobilizações contemporâneas inicialmente mencionadas.

Elas se apresentam a partir de uma série de adjetivações, conformando um objeto "escorregadio", avesso a denominações estáveis. A orientação ideológica de cunho anarquista e autônomo - termos que no campo aparecem muitas vezes como sinônimos parece organizar as categorias que são contingentes, intercambiáveis, e às vezes cumulativas: feministas veganas, feministas libertárias, anakarfeministas, feministas lésbicas, feministas negras, feministas autônomas, transecofeminismo, lesboecofeminismo, feministas lésbicas autônomas, feministas punks, feminismo gordo, feminismo faça você mesma, feminismo

\footnotetext{
1 Doravante, como convenção para a escrita deste artigo, adoto o recurso gráfico do itálico a fim de marcar termos êmicos relevantes, isto é, provindos do trabalho de campo, e estrangeirismos. As aspas serão utilizadas para conceitos e citações.
} 
interseccional são algumas dessas possibilidades de autonomeação acionadas no campo etnográfico.

Usualmente, "rolê" é um termo que carrega sentidos associados a circulação e transitoriedade, o que faz sentido se consideradas as imbricações acima mencionadas. Enquanto gíria, "dar um rolê" remete a dar uma volta sem maiores compromissos, e tem sido usado no universo da pesquisa como uma categoria englobante e articuladora de pertencimento (e exclusões).

Embora a expressão seja associada a atividades lúdicas, no que se refere a sociabilidade e lazer, pesquisas e acontecimentos mais recentes chamam atenção para o caráter político da contestação em termos de raça, classe e gênero presente nos chamados "rolezinhos" (Caldeira, 2014). ${ }^{2}$ Nesse sentido, o termo alude à experimentação, ao nomadismo $e$ ao uso do espaço público - características marcantes do circuito de eventos que perfazem o rolê feminista, nos quais sociabilidade, diversão $e$ ativismo estão entrelaçados. Dito isso, o termo pode oferecer uma contribuição analítica relevante, sinalizando tanto um deslocamento frente a categorias como "cena" e "subcultura", quanto em relação à noção mesma de "movimento social".

Tendo em vista as formas contemporâneas de politização do gênero e da sexualidade e considerando que a autonomia não encerra um significado a priori, este artigo buscará explorar seus significados em ação no rolê, sem perder de vista a sua historicidade. Olhando para os discursos e práticas ativistas, discutirei a materialização da autonomia em práticas como a okupação e seus desdobramentos - como o escracho - no espaço público.

\footnotetext{
2 Recentemente, os chamados "rolezinhos" tomaram projeção nacional. Trata-se de encontros de grande número de jovens da periferia em shopping centers, os quais, como discute Teresa Caldeira (2014), são parte de uma lógica de circulação que articula produção cultural, crítica social e trânsito pela cidade. Eles expressam também transformações recentes nas dinâmicas de classe, raça $e$ gênero. A autora chama também atenção para o uso da expressão "fazer rolê" por parte de grupos de pichadores na cidade de São Paulo, entre outros.
} 
Mais especificamente, dialogarei com a noção de "prefiguração" criada na década de 1970 e hoje utilizada por alguns autores para analisar expressões ativistas recentes, como o Movimento Passe Livre (MPL) (Ortellado, 2013; Bringel; Pleyers, 2015). De modo sucinto, ela diz respeito a busca por construir o mundo que se almeja a partir do espaço habitado no tempo presente. À luz dos dados etnográficos, discutirei potencialidade e limites da terminologia, sem ignorar os conflitos e disputas deflagrados na relação contingente das ativistas com outros atores sociais.

Buscarei também matizar as polarizações do discurso ativista, enfatizando a permeabilidade de fronteiras entre os chamados ativismos cívicos e não cívicos - para usar a nomenclatura proposta por Alvarez et alii (2017). Com isso espero contribuir para a compreensão dos entendimentos nativos em disputa acerca do fazer político no/do rolê, de modo a ampliar a discussão sobre movimentos sociais contemporâneos $e$ modalidades ativistas não institucionalizadas.

Para tal, serão discutidos alguns excertos do diário de campo relativos a momentos de circulação no/do rolê entre os anos de 2015 e 2016. A observação participante se deu em eventos que são pontos nodais, através dos quais ativistas transitam provindas de diferentes estados do país. Considerando que se trata de pessoas que viajam e se visitam com frequência no interior de um circuito de eventos, foi realizada uma etnografia móvel, acompanhando o trânsito das ativistas. Além da observação de eventos $e$ atividades internas à rede, foram coletados documentos etnográficos, como panfletos e fanzines. Também foi realizada observação online em redes sociais como o Facebook.

Farei menção principalmente a dois eventos: a I Feira do Livro Feminista e Autônoma, realizada na cidade de Porto Alegre em 2015, e a Virada Sapatão, realizada em São Paulo no ano de 2016. Em geral, eventos como esses acontecem em locais públicos, como bibliotecas, universidades, espaços anarquistas e centros de 
cultura, assim como em estabelecimentos comerciais de entretenimento, como pequenas casas de show.

Sendo uma pessoa intimamente envolvida com o universo investigado, a liminaridade entre as posições de pesquisadora $e$ ativista se mostrou também uma condição sine qua non para a própria exequibilidade da pesquisa, possibilitando um "mergulho" intenso no campo. Tal ambiguidade foi acompanhada pelo esforço de estranhamento analítico e por precauções de cunho ético, especialmente com relação à publicização de dados provindos da observação participante. Assim, situações dos diários de campo aqui apresentadas dizem respeito a momentos públicos dos eventos. Ciente do meu acesso facilitado ao campo, evitei expor informações relativas a atividades como oficinas, por exemplo, as quais geralmente acontecem em locais fechados, voltadas a um número restrito de pessoas. Além disso, nomes próprios foram omitidos ou substituídos por pseudônimos.

\section{1. "Acabou o patriarcado! Bem vindas à Feira do Livro Feminista e Autônoma!"}

A I Feira do Livro Feminista e Autônoma (FLIFEA) aconteceu na cidade de Porto Alegre (RS), entre os dias 30 de outubro e 2 de novembro de 2015. Entre o público havia mulheres jovens de São Paulo, Rio de Janeiro, Belo Horizonte e de outros estados do Sul e Sudeste brasileiros. A ideia da FLIFEA surgiu a partir de experiência de participação na Feira do Livro Anarquista de Porto Alegre e em grupos como o coletivo local da Marcha das Vadias.

O texto de apresentação definia o evento como

Um espaço que se proponha a ser coletivo e plural na escuta e nas expressões das nossas diferentes vivências feministas, onde possamos nos encontrar para a troca de publicações, materiais, ideias e saberes. Esta é uma iniciativa feminista para afirmar a nossa presença no tempo e na história, problematizando o que é dito, como é dito e por quem é dito. Por isso a feira se posiciona de maneira 
autônoma em relação ao mercado editorial, ao estado, ao capital $e$ a todos os lugares onde o patriarcado se reproduz. Arranquemos os tentáculos das esferas institucionais que produzem mentes e corpos! ${ }^{3}$

A atividade de abertura da FLIFEA aconteceu numa sextafeira, em uma praça em região de atividades culturais de Porto Alegre que abriga cinemas, praças e bares. A praça era extensa $e$ coberta por grama e algumas árvores. Uma faixa de tecido preto foi amarrada entre dois troncos. Em letras roxas, ela anunciava "I Feira do Livro Feminista e Autônoma", com a primeira letra "a" grafada como "(A)" - símbolo associado ao anarquismo. Como em outros eventos, autônomo e anarquista pareciam operar de forma intercambiável como sinônimos.

Os preparativos começaram no entardecer: serrote, corda, vassoura e lenha compunham aquele pedaço da praça. A ideia era realizar um sarau com fogueira, para o qual cada uma era chamada a trazer "sua arte e sua bruxaria". Ao longo da noite, o número de participantes crescia cada vez mais, e quem chegava prontamente se juntava aos esforços de construção do espaço. A lenha foi organizada de modo a formar uma fogueira, velas foram acesas em pequenos sacos de papel marrom que protegiam as chamas do vento, cordas eram usadas para amarrar a faixa e uma refeição era improvisada com pães e tomates.

Havia garotas com camisetas de bandas punks, como Bikini Kill e Green Day. Uma delas sustentava um moicano na cabeça, vestindo calça, bota e camiseta inteiramente pretos. Também havia algumas com uma estética mais colorida, isto é, usando tecidos mais leves e estampados. Porém, em sua maioria, usavam bermuda ou calça e poucas exibiam saia ou vestido. Em termos de apresentação de gênero, algumas se mostravam de forma mais ambígua, com cabelo curto, tênis e camiseta mais solta, sem marcar as curvas do busto; outras tinham cabelo dreadlock ou

3 Disponível em: <https://flifeapoa.noblogs.org/post/2015/07/>. Acesso em 16 ago. 2017. 
tingido de cores como azul. Assim como nos demais dias do evento, a presença de negras era minoritária em termos quantitativos.

Afora o nosso grupo, havia algumas pessoas passeando, mas definitivamente chamamos bastante atenção com uma fogueira acesa em plena praça pública, sem qualquer permissão ou licença formal. Além da fogueira, velas foram acesas ao seu redor, onde cerca de setenta pessoas se aglutinaram, sentadas em cangas e lenços.

Com o anoitecer, as chamas da fogueira $e$ as luzes alaranjadas dos arranjos de velas ganhavam contorno, $e$ foi iniciada a abertura da feira. De pé, próximas ao fogo, duas participantes pertencentes à organização do evento deram as boas-vindas. Nas palavras delas, a I FLIFEA foi mobilizada tendo por objetivo contribuir para construir nossas vidas com autonomia. Essa seria a tônica tanto do conteúdo disponível nas produções a serem expostas, quanto das atividades planejadas para acontecer nos próximos dias. O simbolismo da fogueira foi usado para justificar o formato da abertura do evento: ao longo da história, a fogueira seria um "lugar de encontros" que naquele momento se insurgiriam no espaço da cidade.

Feitas as falas de abertura, alguém do meio da roda gritou uma saudação, de forma efusiva: "Acabou o patriarcado! Bemvindas à Feira do livro feminista e autônoma!", sendo acompanhada por gritos e palmas de reciprocidade.

No dia seguinte, um sábado, teve início propriamente a Feira do Livro Feminista e Autônoma, em outro logradouro público: dessa vez em uma praça pública localizada em região residencial de Porto Alegre, em bairro próximo ao centro da cidade. Embora o maior fluxo de pessoas na praça ocorresse em função da feira, havia alguns transeuntes passeando e moradores com seus cachorros se exercitando.

Como forma de coletivizar o cuidado e a responsabilidade, em uma extremidade da parte cimentada da praça foi improvisado um espaço para crianças levadas ao evento, dispondo de lápis coloridos e papéis. Na outra extremidade foi 
montado um toldo com cadeiras plásticas que às vezes servia de local para oficinas. Em uma das laterais, foi pendurado um tecido translúcido no qual foi fixada uma vassoura de palha, dando a impressão de que estava flutuando solta no ar, como uma referência ao imaginário socialmente associado à figura da bruxa.

Diversos cartazes foram fixados nas pilastras da praça. Os dois maiores foram confeccionados em tecido, com letras em branco e roxo: um deles dizia "I Feira feminista autônoma", sendo que a primeira letra "a" na palavra "autônoma" foi cunhado também como "(A)"; na outra faixa, em tecido roxo, líamos "A nossa força de golpe é da mesma intensidade daquilo que vivemos. BRUXAS RESISTEM!". Cartazes de papel espalhados pela praça pediam: "respeita as minas".

As minas eram o público alvo do evento. Mas o termo não possui sentido unívoco: como dito no blog $^{4}$ da feira, a maior parte das atividades da FLIFEA eram "exclusivas para todas as mulheres, pessoas trans (binárias e não binárias)" e excludentes para "homens cis (pessoas que foram identificadas como homem ao nascer e seguem se percebendo e sendo percebidos como homens na vida)". O debate sobre o sujeito legítimo do movimento feminista vem de longa data. O excerto do diário de campo aponta para a sua atualização em novos termos, reservando ao homem cisgênero a posição de exterior constitutivo. ${ }^{5}$

O cartaz maior fixado a uma das pilastras trazia o título de "ética da convivência autogestionada". Em consonância com a pretendida suspensão de valores e códigos da sociedade mais ampla, ele explicitava os preceitos éticos de uma visão de mundo compartilhada. No cartaz, bastante comum nesses eventos, líamos:

${ }^{4}$ Disponível em: <http://flifeapoa.noblogs.org/post/2015/10/27/programacao/>. Acesso em 18 nov. 2015.

${ }^{5}$ Embora a maior parte dos eventos que observei no role fossem interditos para homens cisgênero, alguns deles - como o Festival Autônomo Feminista ocorrido em São Paulo anualmente entre 2014 e 2016 - permitiam sua presença em certos momentos. Nesses eventos relativamente mistos, era comum ver a presença masculina alocada na cozinha, preparando a refeição, ou na área reservada às crianças, cuidando e entretendo-as. 
- a segurança é feita por todas, procure a grupa de acolhimento em caso de dúvida de demanda específica - bituca não é semente. Procure a bituqueira mais próxima - vamos manter o espaço limpo e organizado

- se você ver uma tarefa por fazer, ela é sua

- aqui não queremos servir nem consumir, mas compartilhar e trocar

- não serão toleradas atitudes machistas, racistas, transfóbicas

Algumas participantes chegavam de bicicleta na feira, estacionando-as nos bancos da praça e pilastras, e outras a pé. $\mathrm{O}$ espaço era dividido por mesas ou balcões onde certos artefatos eram expostos, vendidos ou trocados. Entre os estandes foi posto um fogão portátil com uma grande panela na qual era preparada a refeição coletiva gratuita e servida, de forma improvisada, em potes plásticos de embalagens descartáveis reutilizadas $e$ compartilhados. Em todos os dias da FLIFEA os alimentos servidos eram estritamente vegetarianos, isto é, veganos. Em troca, pediase "contribuição voluntária".

A partir da construção de relações sociais de oposição à organização hierárquica e centralizada (rejeitando, por exemplo, a divisão entre base e liderança e a delegação de funções), o evento emerge como um espaço de experimentação coletiva de novos arranjos e condutas. Ele dá lugar a locais temporários de autogestão, os quais seriam livres de machismo, racismo $e$ transfobia. Igualmente, é parte da antecipação da sociedade almejada o caráter anticapitalista, que estimula a predileção pelas "trocas" e partilhas ao invés das relações de "consumo".

A noção de que o início da FLIFEA marcava o término do patriarcado, assim como os cartazes espalhados pela praça, refletem alguns dos códigos e regras de convivência que regiam aquele espaço no qual deveria prevalecer a suspensão de certos valores e práticas da sociedade mais ampla, evocando a discussão sobre políticas prefigurativas. 
Em geral, o termo "prefiguração" se refere a cenários nos quais ativistas expressam os "fins" políticos das suas ações através dos "meios", ao invés dos "fins" justificarem os "meios" (Yates, 2015). Na bibliografia, "políticas prefigurativas" ou "prefiguração" são termos intercambiáveis, e estão associados a outras terminações, como "micropolíticas" e "ação direta". Grosso modo, o conceito diz respeito a tentativas de construir relações sociais utópicas ou alternativas no presente, de modo a antecipar a sociedade almejada.

De acordo com Yates (2015), o termo foi cunhado por Carl Boggs, em 1977, a fim de denotar uma lógica política em pretendida oposição ao "marxismo estatal", sendo desde então utilizado no debate acerca das tensões entre "comunidade" $e$ "organização" dentro da New Left estadounidense, na década de 1970.

Em muitos trabalhos sobre aquele contexto, "políticas prefigurativas" foi usado para se referir a uma dinâmica que distinguiria projetos políticos de esquerda ou estilos de protesto de esquerda à parte do trotskismo $e$ do leninismo, nos quais uma organização ou vanguarda seriam consideradas necessárias para trazer a revolução. Em crítica ao autoritarismo das tentativas passadas de socialismo de Estado, a prefiguração é dita para criar ou prefigurar alternativas utópicas, embora numa escala limitada, no presente (Yates, 2015).

Atualmente, a terminologia tem jogado papel significativo nas discussões dos movimentos contemporâneos, incluindo os movimentos antiglobalização, de ação direta ambiental, a ocupação de espaços públicos em 2011 no Egito, Grécia, Espanha, Estados Unidos e Inglaterra, modos alternativos de consumo e abastecimento, entre outros. O termo aparece associado ao que tem sido chamado de "novos movimentos sociais" e está implicado nos debates mais amplos nos estudos sobre política e cultura (Yates, 2015). 


\section{2. "Okupar é resistir"}

Apesar da sua importância nesses debates, as discussões sobre políticas prefigurativas estão baseadas em alegações difusas, que geram dificuldades teóricas e questões empíricas. Nem sempre está claro se a prefiguração é uma tática, uma orientação ou um jeito de fazer protesto, um tipo alternativo de movimento ou uma combinação disso, como problematiza Yates (2015).

De fato, a categoria evoca muitas interpretações. É impreciso ao que se refere à prefiguração da sociedade vindoura: ela estaria relacionada à ação direta como forma de intervenção no social por meio de determinada performance, como a prática do catracaço ${ }^{6}$, por exemplo? Ou, antes, ela estaria embutida nos formatos organizativos que prescindem de lideranças formais e nas tomadas de decisão por meio de assembleias horizontais?

Yates identifica duas formas como o termo tem sido utilizado na literatura:

1) Em certos enquadramentos conceituais o termo é usado para fazer menção a um modo de conduzir protestos $e$ tomadas de decisão coletivas de forma não hierárquica. $\mathrm{O}$ exemplo típico seria a produção de consenso, a "democracia direta" e mecanismos usados para promover tomadas de decisão igualitárias - como nos protestos antiglobalização em Seattle (1999), quando manifestantes em assembleia gritavam a palavra de ordem "This is what democracy looks like!'. Segundo Yates, seriam proponentes dessa corrente autores como Boggs e Graeber.

2) Para a segunda corrente, prefiguração diz respeito à construção de comunidades ou instituições "alternativas" enquanto sociabilidade $e$ formatos organizativos de

${ }^{6}$ Para o MPL, "[...] o catracaço é a implementação prática da Tarifa Zero. Pode ser feito com a abertura das portas traseiras do ônibus ou pulando as catracas" (MPL, 2013:13). Nessa categoria poderiam ser incluídos também os escrachos, a serem tratados adiante. 
movimentos sociais. Epstein e Breines seriam alguns dos teóricos dessa perspectiva.

É comum às duas visões a noção de prolepse, de acordo com a qual "prefigurar" consiste em antecipar ou mobilizar no presente algumas características de um mundo aspirado. De acordo com o autor, pesquisadores e estudiosos da área continuam a tratar as políticas prefigurativas principalmente como uma das duas dinâmicas, embora exista uma série de justaposições entre elas.

A simples noção de equivalência entre meios e fins não ajuda na compreensão das ações políticas nomeadas como prefigurativas. Não está claro a quais processos e objetivos se faz referência. Esse tipo de elaboração, argumenta Yates, é impreciso na medida em que movimentos têm múltiplos objetivos e se engajam em grande variedade de práticas, processos e "meios".

Propõe-se que a prefiguração é melhor compreendida como uma configuração plural de práticas, compreendendo as duas dinâmicas e suas justaposições. A fim de complexificar a relação entre práticas $e$ as finalidades ou objetivos da luta, Yates propõe que a equivalência meios-fins significa: a) que há uma ênfase nas "micropolíticas" de como práticas coletivas são performatizadas através de certa homologia com um ou mais objetivos do movimento; b) essa relação é sempre parcial e o tipo de homologia entre práticas e objetivos varia a depender do grupo em questão.

Ademais, os dados do campo etnográfico sobre o rolê feminista desvelam uma lacuna nesse debate no que tange o lugar do corpo. Nessa seção, argumentarei que a prefiguração denota experimentação - entendida como algo que se tem a intenção de testar, sem ter certeza ou estar segura sobre os resultados, orientada à produção de novos códigos e tendo como objetos de intervenção o corpo, o tempo e o espaço. Adiante, apontarei que à experimentação somam-se constrangimentos sociais como dimensão igualmente constitutiva. 
Sendo assim, o que também está em questão nesse debate é a própria noção temporal de futuro, que muitas vezes parece estar ausente do horizonte de ação das ativistas, dada a sua ênfase no presente imediato acessado pelos eventos. A relação tempoespaço que subjaz a essas atividades pode ser entrevista em uma ilustração (Figura 1) exposta em banquinha de evento realizado na cidade de São Paulo em agosto de 2016, nomeado Virada Sapatão (VS). Nele, uma personagem desenhada à mão aparece mastigando um relógio que apresenta fissuras:

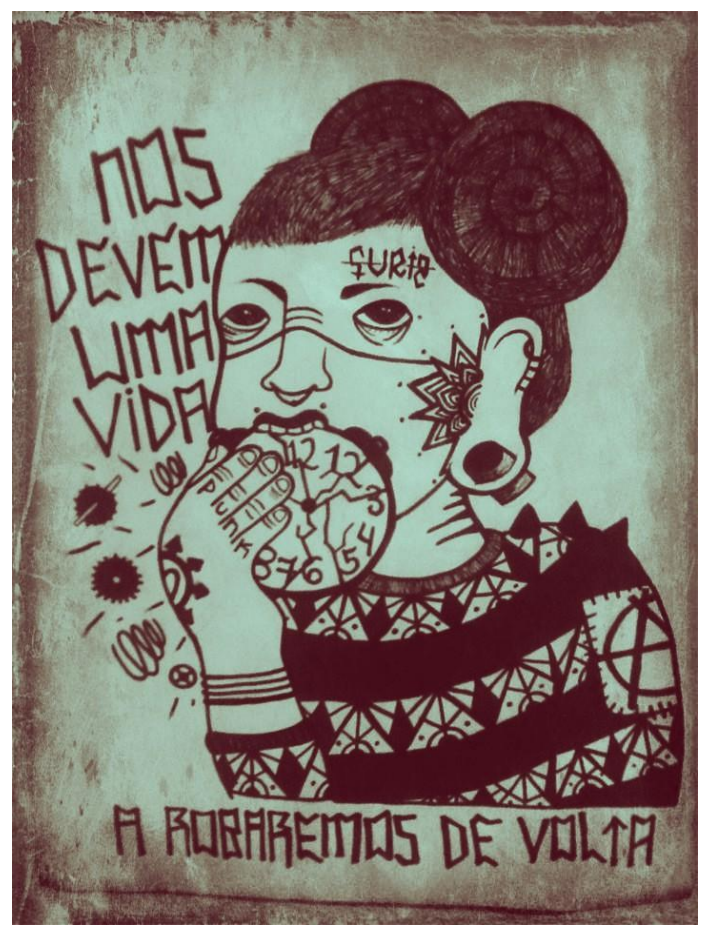

Figura 1 Disponível em: <http://dibujosdecapucha.tumblr.com/post/142356470520/pesoda-morte-em-vida-enclausurar-se-nos-po\%C3\%A7os>. Acesso em 12 dez. 2016.

A própria noção de "virada" carrega sentidos associados ao manejo do tempo. O tempo como objeto de intervenção é o tema da ilustração, em que as rachaduras no relógio materializam a 
busca por uma maneira não rotinizada de vivenciar o corpo, o tempo e o espaço, de modo a tomar de volta uma vida percebida como roubada. Tal experimentação é por vezes traduzida por meio do termo êmico ocupação ou okupação, remetido tanto ao espaço e à rua, quanto ao corpo, enquanto dois polos de um contínuo a ser ocupado, retomado. Como afirmou uma interlocutora em outra ocasiáo, "temos que ocupar os nossos corpos também!".

A Virada Sapatão ${ }^{7}$ aconteceu no mês de agosto, considerado no calendário ativista como o Mês da Visibilidade Lésbica. Entre as atividades, aconteceram uma roda de conversa sobre violência entre lésbicas, oficina de escrita, oficina de rádio, roda de conversa sobre lesbianidade negra, roda de conversa sobre branquitude e exibição de filmes, para nomear algumas. $\mathrm{O}$ evento contou com aproximadamente 24 horas de atividades na programação, ao longo da qual chegou a ter cerca de 100 participantes em um espaço coletivo situado em um bairro na Zona Norte da cidade de São Paulo, que se localiza a cerca de 10 quilômetros do centro geográfico da cidade. O lugar se define como uma "uma casa de lésbicas, feministas, autônomas, que busca construir espaços de troca, coletividade e sororidade."

Assim como a figura da bruxa, o uso de sapatão é parte de estratégia de positivação de categorias acusatórias. $\mathrm{O}$ termo expressa a assunção de uma identidade lésbica que, como coloca Facchini (2008:161) sobre as dykes, está "associado a comportamentos e/ou aparências tidas convencionalmente como 'masculinas", e a "manter uma postura de enfrentamento com os homens, quando se acredita que estes estejam invadindo seu espaço ou cerceando, de alguma forma, a sua expressão". 8

7 O nome é uma provável referência ao evento Virada Cultural que acontece anualmente na cidade de São Paulo, organizado pela prefeitura.

8 À época, a autora notou que o uso do termo parecia "não pressupor uma correlação necessária entre práticas afetivo-sexuais e identidades" (Facchini, 2008:158), ou seja: "ter experiências sexuais com mulheres não faz de alguém uma dyke, nem faz com que quem experimenta ou mesmo tem relações casuais com outra mulher deixe de ser considerada hétero" (Facchini, 2008:159). 
Diferentemente da FLIFEA, a Virada Sapatão aconteceu em uma casa dentro de vila residencial, que funciona tanto como espaço de moradia coletiva quanto como centro cultural autônomo. O fluxo de pessoas e o som emitido pelos shows $e$ conversas informais dentro e nos arredores do imóvel foram objeto de preocupação da organização, pois a presença repentina da polícia não era incomum em eventos como esse no local. A programação contava também com uma saída às ruas do bairro para fazer intervenções em muros e postes por meio de lambelambes e inscrição com spray utilizando moldes vazados (estêncil). Sendo assim, nota-se certa continuidade entre público/privado, casa/rua - atravessada por muitas tensões, como discutirei ao longo deste artigo.

Como já mencionado, a Feira em Porto Alegre também tomou corpo na ocupação de praças públicas, alterando a paisagem $e$ a rotina do entorno dos logradouros durante aqueles quatro dias. Conforme sugere Raquel Rolnik (2013), coletivos que reivindicam o direito à cidade, como o MPL (Movimento Passe Livre), fazem de grandes cidades brasileiras não só palco de suas ações, como objeto de intervenções desses próprios coletivos. A autora pondera que, se na linguagem da polícia a ocupação das ruas significa baderna, para diversos movimentos sociais a retomada do espaço urbano constitui não só um objetivo como um método.

De acordo com sua visão, a ocupação da rua não seria em si algo novo na política, mas é recente o seu "sentido de controle do espaço, mesmo que por um certo período, e, a partir daí, a ação direta na gestão de seus fluxos" (Rolnik, 2013:10). Desse modo, ocupar as ruas equivaleria a reorganizar os espaços fazendo uso do próprio corpo como "ação direta".

Em seu livro de 2015, "Notes toward a performative theory of assembly", Judith Butler (2015) chama atenção para o corpo

Considero que a expansão do uso de categorias de autonomeação como sapatão, sapa e caminhão é, em certa medida, caudatária da cena das minas do rock investigada pela autora entre 2004 e 2007. 
nos protestos e demonstrações em espaços públicos ${ }^{9}$, ao repensar e alargar a noção de performatividade - inicialmente desenvolvida para analisar o exercício performático do gênero e a sua materialização (Butler, 2003, 2010). Informada pela crítica feminista, ela traz uma contribuição relevante ao apontar para a importância não só das demandas vocalizadas nos discursos em praças e ruas, mas nos atos corporais coletivos que buscam reconstruir formas de agência e práticas de resistência.

Para a autora, quando corpos se reúnem na rua, na praça ou em outras formas de espaço público, incluindo espaços virtuais, eles estão exercendo o "direito performativo de aparecer" (performative right to appear) - um direito que afirma e instala o corpo no meio do campo político e que, na sua dimensão expressiva e simbólica, produz demandas corporificadas por uma vida mais "vivivel". A assembleia exprime uma forma provisória de coexistência na qual os corpos reunidos "falam", mesmo que se mantenham em silêncio - assim, a performatividade diz respeito não só ao discurso e atitudes heroicas, mas às demandas colocadas nas ações dos corpos, como gestuais, movimentos, congregações, persistência e exposição dos corpos à possível violência e repressão. Para a autora, essas demonstrações podem pôr em questão certas dimensões das noções vigentes acerca do político e da divisão público-privado.

Embora motivadas por razões políticas distintas, as demonstrações coletivas que tomam ruas e praças possuem algo em comum: corpos se congregam, movem-se, falam entre si $e$ reivindicam aquele espaço como público. Butler discorda das

${ }^{9}$ Quando fala em demonstrações públicas, Judith Butler (2015) está pensando nos protestos na Praça Tahrir no Egito em 2011, no movimento Occupy nos EUA, nas lutas por educação pública no Chile, e mobilizações para fazer das ruas espaços seguros para minorias sexuais e de gênero, incluindo pessoas trans, cuja aparição é frequentemente punida por meios legais ou ilegais. Para ela, há em comum a essas mobilizações a luta contra a condição social e econômica de precariedade - por sua vez, vista como a rubrica que reúne mulheres, queers, pessoas trans, pobres, pessoas com deficiência, imigrantes sem documento, $e$ minorias raciais e religiosas. 
análises que caracterizam esses movimentos apenas como corpos que se encontram para elaborar demandas no espaço público. Para ela, formulações desse tipo têm como pressuposto um espaço público que está dado, que já é público e reconhecido enquanto tal, falhando em ver que o próprio caráter público está sendo disputado. Praças e ruas não são meros suportes materiais para a ação. ${ }^{10}$ São parte da ação pública corporificada. A assembleia pública reconfigura a materialidade do espaço público, cujos equipamentos são ao mesmo tempo parte e agentes da ação (Butler, 2015). Além de trazer o corpo para o centro da análise algo ausente na literatura citada sobre políticas prefigurativas -, as considerações da autora são relevantes para a noção de ocupação aqui discutida e o(s) tipo(s) de prefiguração por ela mobilizado(s).

Há debates intensos dentro do espectro da esquerda envolvendo as questões acima tratadas tanto no campo político quanto acadêmico. Por exemplo, Farber (2014) coloca os teóricos da política prefigurativa em oposição aos "esquerdistas estratégicos" os quais defenderiam que não é possível "préfigurar" a sociedade futura pois os movimentos estão inexoravelmente sujeitos às pressões do capitalismo e do Estado. Para o autor, a política prefigurativa nega a centralidade do Estado e isso leva a ignorar a necessidade de demandar $e$ formular exigências políticas ao governo.

$\mathrm{Na}$ leitura de Farber, os proponentes da prefiguração defendem uma concepção muito estreita de democracia. Isto é, uma vez que eles estariam em oposição à delegação de funções,

isso tende a gerar longos debates sobre temas triviais que substituem discussões politicamente mais relevantes. Nesse sentido, às vezes, a prática democrática se reduz a decidir democraticamente quem fará a limpeza ou quem trará a pizza (Farber, 2014:82).

\footnotetext{
${ }^{10}$ As considerações de Butler sobre espaço e equipamentos públicos têm influência dos estudos sobre deficiência e o entendimento da agência de atores não humanos, como a autora dá a entender na página 72 de "Notes toward a performative theory of assembly' (2015).
} 
Isso excluiria a maior parte das pessoas que estão ocupadas com obrigações familiares e profissionais e portanto não têm "tempo ilimitado para militar". ${ }^{11}$

Uma crítica similar é formulada por Ortelado (2013) na sua análise sobre as Jornadas de Junho. Na visão do autor, movimentos como os protestos de junho de 2013 são constituídos por uma tensão entre a dimensão processual e os resultados práticos da ação política. Haveria uma sobrevalorização do processo a despeito dos resultados, de modo que a ênfase recairia sobre o meio pelo qual atuam: eles veriam a democracia radical $e$ a ideia de uma sociedade livre e igualitária não como uma meta, mas como algo a ser antecipado no próprio processo de luta, de forma prefigurativa. Assim, as opções táticas não seriam julgadas com respeito aos resultados práticos da luta, mas à integridade do idealismo. As assembleias seriam exemplo flagrante dessa tensão, onde "tudo o que já foi dito precisa ser dito outra vez por quem ainda não falou", pois a questão não consistiria em tomar uma decisão que contemple a pluralidade de perspectivas constitutivas da coletividade, mas também se trata de dar lugar a autoexpressão e a participação em uma experiência comunitária.

Todavia, a análise em termos de processo versus resultados obscurece o lugar da experiência, da sociabilidade e do lúdico como aspectos inseparáveis do próprio fazer político alicerçado na politização do cotidiano. Como colocam Facchini e Rodrigues

\footnotetext{
${ }^{11}$ Faber segue a sua crítica defendendo a concepção de Lênin de "tribuno popular" e acrescenta: "Infelizmente, essa estratégia política ampla não se vê favorecida pela tendência comum entre parte da esquerda pós-Occupy de reforçar as situações de privilégio e de se acusar mutuamente de racismo, sexismo, homofobia, transfobia, susceptibilidades sobre a imagem corporal, entre outros aspectos, sem nenhuma consciência sobre como construir um movimento que defenda uma política de solidariedade com os oprimidos (a opressão é uma opressão a todos). É a política de uma "seita" pura (para empregar o termo do teórico político de esquerda Sheldon Wolin), em contraposição àquelas que reivindicam uma política de solidariedade" (Farber, 2014:84).
} 
(2017) a respeito de inflexões recentes no movimento LGBT e que se fazem presentes também no rolê feminista,

A interlocução parece se deslocar de um foco predominante na figura do Estado como administrador de demandas, com agendas a serem disputadas [...], na direção da disputa da opinião pública e da intervenção visando "descontruir preconceitos" (Facchini; Rodrigues, 2017:51).

$\mathrm{O}$ que requer um olhar aberto aos significados nativos atribuídos ao próprio fazer político, os quais, nesse caso, parecem prescindir da separação mesma entre processos e resultados.

Além disso, como será explorado na próxima seção, a ocupação enquanto estratégia prefigurativa só pode ser entendida enquanto localizada em um contínuo de gradações entre o cívico $e$ o não cívico, seja em relação de conflito como de tensão produtiva (Alvarez et alii, 2017). Essa dimensão está ausente nos autores acima, os quais, como Farber, tomam o Estado como uma instituição monolítica.

Como Alvarez et alii (2017) chamam atenção, os âmbitos cívico e não cívico da participação são constantemente tratados de forma dualista. Os críticos que apontam uma suposta supervalorização da dimensão processual em detrimento dos resultados ou objetivos parecem se lastrear nessa divisão. Decorre que o debate contemporâneo muitas vezes se divide em duas vertentes cujas pressuposições são questionadas pelos autores: 1) As ciências sociais de tendência liberal tendem a afirmar que ações políticas protagonizadas pela sociedade "não cívica" ameaçam a democracia, ao passo que a participação da sociedade civil nas instituições governamentais e intergovernamentais tenderia a aperfeiçoar ou expandi-la; 2) Já para a outra vertente, ações como protestos de rua e de ação direta seriam os responsáveis por avançar a democracia - os autores lembram que esse repertório tem sido apropriado por atores conservadores, como grupos que pressionaram pelo impeachment de Dilma Rousseff (Alvarez et alii, 2017). Como será explorado adiante, os autores propõem um 
quadro interpretativo que considere as contaminações e tensões que ocorrem entre os diversos âmbitos da participação e a diversidade de atores políticos que tem ganhado visibilidade na última década.

\section{Negociando fronteiras}

Tomei conhecimento da realização da Feira do Livro Feminista e Autônoma no mês de julho de 2015, por meio do site Facebook, quando uma amiga compartilhou na rede social o endereço do blog do evento, junto a um dos cartazes de divulgação. Sendo direcionada ao endereço eletrônico "flifeapoa.noblogs.org", passei a visitá-lo com frequência. Em agosto, foi divulgada uma chamada para confecção de cartazes, de acordo com a qual todas aquelas que se sentissem "chamadas a somar" poderiam enviar a sua arte a fim de colaborar na divulgação. Posteriormente, onze cartazes foram adicionados à galeria do blog.

Em agosto também foi iniciada uma chamada para a construção coletiva da programação da Feira: as interessadas em propor bate-papo, oficina, filme, debate ou outro tipo de atividade poderiam enviar a proposta por e-mail. Convocações a reuniões presenciais abertas às colaboradoras também foram veiculadas no blog, assim como havia referências ao e-mail e fórum da FLIFEA no servidor RiseUp.

O RiseUp é um servidor criado e gerido por coletivo de mesmo nome que oferece ferramentas de comunicação online, como conta e lista de e-mail, fórum e outros recursos. O coletivo tem sede na cidade de Seattle (Estados Unidos) e membros em diversas partes do mundo. Segundo o próprio site, o projeto tem em vista a criação "de alternativas democráticas para a prática da autonomia, por meio do controle dos nossos próprios meios de comunicação segura", sendo voltado para "pessoas e grupos trabalhando em mudanças sociais libertárias". ${ }^{22}$ A "comunicação

${ }^{12}$ Disponível em: <https://help.riseup.net/pt>. Acesso em 26 nov. 2015. 
segura" é construída em contraponto ao "monitoramento das redes" por parte de governos e a falta de confidencialidade dos "provedores de emails corporativos":

Não existe email gratuito. Serviços como gmail, hotmail, $e$ yahoo fazem dinheiro a partir da vigilância: eles constroem um perfil sobre seu comportamento e bombardeiam anúncios direcionados a você.

Riseup.net é diferente. Esse serviço é um trabalho de amor por ativistas como você, comprometidas com a construção de ações e infraestruturas de segurança alternativas. ${ }^{13}$

De acordo com o coletivo RiseUp, o e-mail do provedor homônimo não registra o endereço IP do usuário, de modo que não é possível identificar o seu local, como acontece na maioria dos serviços. Além disso, as informações trocadas, assim como os dados pessoais de usuários armazenados são criptografados. Com intuito semelhante, o blog da Feira foi hospedado na plataforma Noblogs.org, cujo lema é "Connecting radical people. Non commercial, antifascist, antisexist, privacy-oriented blog platform". ${ }^{14}$

Em setembro, à revelia da postura da organização da FLIFEA, uma página intitulada "Porto Alegre Cultura" criou $e$ manteve online um evento público no Facebook com o nome de " $1^{\text {a }}$ Feira do Livro Feminista e Autônoma". Em resposta, foi publicada uma "Nota de repúdio" no blog da FLIFEA, segundo a qual a criação do evento pela página citada, que não tem relação com a organização da Feira, se mostrava uma tentativa "desonesta" e "oportunista" de "captura, sequestro, assimilação e controle". Enquanto iniciativa autônoma, a "segurança na internet" passa pela resistência ao Facebook ${ }^{15}$ :

\footnotetext{
${ }^{13}$ Disponível em: <https://help.riseup.net/pt/email >. Acesso em 26 nov. 2015.

${ }^{14}$ Disponível em: <https://noblogs.org/>. Acesso em 26 nov. 2015.

${ }^{15}$ Para uma análise crítica de como se dá o uso e a coleta de dados de usuários na rede social Facebook visando a produção de estatísticas, a construção de
} 
Sabemos que essa rede social é atrativa aos olhos e aos egos, e que parece grande coisa ter milhares de curtidas ou confirmações de presença, mas pra nós é muito mais significativo garantir nossa segurança pessoal e coletiva $e$ não nos expormos à vigilância que essa ferramenta permite sobre as nossas vidas. ${ }^{16}$

Ao ver da FLIFEA, a criação do evento cumularia numa exposição descuidada. A fim de garantir a segurança das pessoas presentes no evento, a estratégia adotada consistia em utilizar apenas o e-mail e o blog como canais de divulgação e diálogo. Ademais, os endereços dos locais físicos onde a feira seria realizada foram divulgados apenas poucos dias antes do início do evento. ${ }^{17}$ Esses dados são relevantes pois apontam para um conjunto de precauções que associam certo hermetismo à segurança, a fim de salvaguardar a realização do evento, como será discutido nessa seção.

Com o título de "Quem é bem vinda?", uma publicação feita no mês de agosto no blog da FLIFEA afirmava:
A circulação na Feira é aberta para todas as pessoas. Para expor banca e propor atividades são bem vindas todas que se considerem feministas e não sejam pessoas que foram designadas homens ao nascer e continuem vivendo $e$ se identificando dessa forma. Consideramos que diferentes

perfis comportamentais e a venda de publicidade dirigida, ver Ortiz e Silveira (2013).

${ }^{16}$ Disponível em: <http://flifeapoa.noblogs.org/post/2015/09/18/sobre-o-eventode-facebook-criado-pela-pagina-porto-alegre-cultura/ > . Acesso em 26 nov. 2015. 17 "Muitas pessoas nos perguntam sobre onde acontecerá a FLIFEA-PoA, e essa inquietação aumenta com a proximidade da data. Queremos, portanto, avisar que, por diversos motivos, o local de realização da Feira será divulgado apenas nos dias próximos ao seu acontecimento. Temos nos ocupado em garantir que estejamos num lugar que nos permita a autonomia que precisamos para poder compartilhar nossos saberes de maneira tranquila e confortável num lugar acessível, em breve avisaremos como chegar até lá." Disponível em: $<$ http://flifeapoa.noblogs.org/post/2015/09/28/local-da-feira/>. Acesso em 26 nov. 2015. 
concepções de feminismos são bem vindas e necessárias para contemplar nossas diferentes vivências. Cada atividade terá seu nível de exclusividade definida por quem a propõe, portanto podem haver atividades exclusivas por gênero, sexualidade e raça, e estes espaços devem ser respeitados. Convidamos todas as presentes a que coletivamente acolham e deem apoio em situações em que alguém se sinta ameaçada, coagida, em risco ou oprimida. ${ }^{18}$

A noção de okupar um espaço público não anula por completo as disputas que surgem com o uso compartilhado desses locais com outros atores - especialmente se tratando das praças em finais de semana, cuja circulação de pessoas pode se dar por diversas finalidades. Assim, a organização da Feira lançou mão de estratégias de regulação do acesso ao evento, em consonância com as precauções no âmbito online. Abaixo, em face da discussão sobre segurança e autonomia, buscarei indicar os limites e negociações de fronteiras em eventos como esse, cuja lógica pressupõe ameaças externas, apresentando alguns dos seus momentos contenciosos em descrições do diário de campo.

Cena 1

No sarau de abertura da FLIFEA, um homem branco, desconhecido, que passava pelo local, insistiu em se manter próximo à fogueira, olhando fixamente para o grupo. Logo algumas participantes se dirigiram a ele, de forma intimidadora. "O espaço é delas agora!?", ele esbravejou. "Vou abrir um B.O. contra vocês!" - e gerava reações de riso. "Vaza, vaza!" gritavam as garotas. Uma delas chegou a pegar um graveto de madeira $e$ ameaçar jogar sobre o homem, que então se retirou após momentos de tensão quase física. "Ele chamou a gente de sapatão!", "Que coisa ruim, né?" - comentavam em volta da fogueira, em chacota. Durante alguns minutos toda a atividade foi

${ }^{18}$ Disponível em: <http://flifeapoa.noblogs.org/post/2015/08/24/quem-e-bemvinda/>. Acesso em 26 nov. 2015. 
interrompida em função da sua presença. Ao longo do evento a situação se mostrou relativamente recorrente.

Cena 2

Estava distraída entre as banquinhas de zines, quando notei uma movimentação estranha. Uma garota da organização tentava comunicar que algo inesperado estava acontecendo. Foi quando avistei, na parte da praça que havia sido coberta com as lonas, um homem branco alto, robusto, de bigode, cerveja Polar na mão, calça jeans e camiseta branca, que, em explícita provocação, se lia "machista" em caixa alta na cor vermelha, e logo abaixo a frase "Porque não é errado ser homem". Imediatamente, garotas passaram a se dirigir a ele, que permanecia imóvel e calado, braços cruzados com a cerveja na mão, em posição altiva.

Enquanto algumas observavam e pediam para "Não dar ibope", outras partiram para a intimidação com o objetivo de que ele fosse embora. ${ }^{19}$ Mas ele ligou a câmera do celular e filmou a situação, irritando-as ainda mais. Por instantes, tomaram o aparelho dele com o objetivo de apagar o que havia sido filmado, mas logo o devolveram. Formou-se um círculo em torno do homem aos gritos de "sai fora, machista" e algumas começaram a empurrá-lo quando outro homem apareceu tentando defendê-lo. Ao meu lado, algumas comentavam que não devíamos dar a atenção a ele. Ao mesmo tempo, cerca de vinte garotas o cercaram - "Pega seu celular e vai embora!" - e corporalmente o pressionaram a entrar no carro e deixar o local, à sua revelia.

De acordo com uma informante, trata-se de um youtuber já conhecido por ativistas de Porto Alegre, cuja prática consiste em "invadir" eventos desse tipo e deliberadamente se envolver em conflitos e discussões, sempre munido de aparelho de celular com câmera. Posteriormente, tive a informação de que "o machista" publicou um vídeo no site Youtube como testemunho da

19 "Ibope" é a sigla para Instituto Brasileiro de Opinião Pública e Estatística. O termo é usado no senso comum como sinônimo de audiência. 
"agressão" que teria sofrido por parte das feministas. O episódio indica não só reações implicadas na ocupação da praça e disputa do espaço público, como também reações à ocupação também da internet.

Machista parece figurar aqui como uma espécie de identidade política, fenômeno conhecido como "masculinismo", que alude a defensores dos "direitos dos homens" sobre o qual Lola Aranovich tem escrito extensamente em seu blog. ${ }^{20}$ Eles fazem parte do cotidiano das interlocutoras desta pesquisa. Ademais, é de valia notar que o youtuber que invadiu o evento tem vínculos com atores que foram responsáveis, em 2017, em promover o cancelamento da exposição Queermuseu no Santander Cultural em Porto Alegre (RS), como o MBL (Movimento Brasil Livre). ${ }^{21}$

Cena 3

$\mathrm{Na}$ segunda-feira, dia 02 de novembro e último dia de FLIFEA, fui surpreendida quando, em Porto Alegre, acordei e, ao ligar o computador e acessar o Facebook, me deparei com uma foto desfocada de uma garota com o rosto bastante ensanguentado. Era o rosto da Lia, que então tinha cerca de 22

\footnotetext{
${ }^{20}$ Mais informações estão disponíveis em: <http://escrevalolaescreva.blogspot.com.br/2012/05/o-masculinismo-como-elee.html>. Acesso em 19 fev. 2016.

${ }^{21}$ Ele aparece ao lado dos youtubers de direita Rafinha BK e Felipe Diehl em vídeo que viralizou e serviu de estopim para o cancelamento da mostra "Queermuseu - cartografias da diferença" promovida em Porto Alegre no Santander cultural no ano de 2017. Publicado no site Facebook, o vídeo obteve mais de 1 milhão de visualizações. No vídeo ele veste a mesma camiseta em que se lê "Machista, porque não é errado ser homem". O método é o mesmo utilizado na FLIFEA: adentram a exposição portando câmera filmadora, à revelia das normas internas do museu e da intervenção dos seguranças, expondo rostos de visitantes, funcionários e demais que lá estavam; o vídeo acaba no momento em que são expulsos do local. De acordo com reportagens, são atores próximos ao MBL. O ataque à mostra é parte de um cenário de recrudescimento conservador que tem como alvo a chamada "ideologia de gênero" e a defesa do projeto de lei "Escola sem partido".
} 
anos, e cursava jornalismo. Com sua pele branca, cabelos claros, lisos e curto, o sangue espesso escorria do início da testa até a boca, de modo a tomar metade do seu rosto. A postagem havia sido veiculada através da página "Putinhas Aborteiras Anarkafunk e Anarkarap" e tinha por título, em caixa alta, "Chamado urgente de solidariedade! Agressão policial na $1^{\text {a }}$ Feira do Livro Feminista e Autônoma de Porto Alegre". Abaixo, lia-se o seguinte texto:

Desde o início da FLIFEA sofremos perseguições e agressões machistas e fascistas, com ameaças, provocações $e$ presenças hostis, que foram constatadas e enfrentadas em cada momento. Mas o que aconteceu nesta noite de domingo (01/11/15) merece uma denúncia específica para apontar a violência estatal que expressa a misoginia institucional que violenta mulheres sistematicamente.

$\mathrm{Na}$ noite de domingo estava acontecendo um ensaio artístico, com a presença de em torno de 20 mulheres, $e$ uma viatura chegou com dois policiais que vieram supostamente devido ao barulho. Eles filmaram $e$ intimidaram as mulheres presentes que estavam falando com eles, o que gerou reações de proteção entre as mulheres, como se organizar para ir embora e filmar a situação. Em seguida chegaram outras viaturas com mais policiais que foram extremamente agressivos $e$ marcadamente racistas desde o início e tentaram deter uma de nós de maneira violenta, o que desencadeou uma série de agressões físicas por parte da polícia das quais nove mulheres ficaram feridas, sendo que quatro gravemente $e$ precisaram de atendimento médico.

Muitas agressões aconteceram de maneira simultânea, havendo inclusive policiais que sacaram armas de fogo um deles sacou uma arma e ameaçou várias de nós dizendo "eu vou queimar você". Entre as ameaçadas nessa situação, uma das mulheres inclusive avisou que estava grávida, o que não foi relevante para os policiais. Dois moradores que estavam na praça no momento do ocorrido também foram agredidos com cassetetes pela polícia. As mulheres que estavam com celulares foram alvo específico 
de agressões, e dois celulares foram roubados pelos policiais. Algumas das mulheres que tentavam fugir eram perseguidas $e$ derrubadas $e$ não conseguiam sair das agressões dos policiais, caídas no chão apanhavam com cassetetes e chutes, enquanto outras voltavam pra colocar seus corpos como escudos para tentar protegê-las e tirá-las dali. Essa cena se repetiu sucessivamente, e em meio a espancamentos com cassetetes as mulheres conseguiram chegar até as proximidades do Hospital de Clínicas, quando os policiais finalmente dispersaram.

$* * * * * * * * * *$

Em nenhum momento companheiras ficaram para trás, conseguimos nos reunir em segurança para escrever este relato e para chamar a solidariedade de todas as pessoas que possam nos apoiar neste momento. A feira está programada para continuar suas atividades na segunda feira (02/11/15), a partir das 10 horas, no mesmo local onde ocorreram essas agressões. Precisamos de apoio nesta manhã!

$* * * * * * * * * *$

Considerando que mulheres chegarão desavisadas do ocorrido, temos que nos fazer presentes e precisaremos de todo o apoio possível. Começaremos o dia com uma roda de conversa sobre essa situação. Precisamos da presença da maior quantidade de pessoas possível para garantir a continuidade da feira nesse último dia. É assim que a gente revida, não nos calando e resistindo juntas não apenas na disputa pela rua e o espaço público mas também contra um sistema que não admite a auto-organização de mulheres $e$ que se sente ameaçado pela nossa existência insubmissa. Foi escancarado o acréscimo de ódio que a misoginia teve nesse episódio e sentimos que isso precisa ser enfrentado pela nossa sobrevivência, por todas nós que vivemos na guerra desse mundo contra as mulheres. ${ }^{22}$ 
A página no Facebook que divulgou a nota acima diz respeito a um grupo de Porto Alegre cujas músicas foram trilha sonora em diversos momentos da FLIFEA, sendo uma referência recorrente no evento. $\mathrm{O}$ grupo Putinhas Aborteiras tomou corpo após julho de 2013, quando integrantes participaram da chamada Jornadas de Junho e da ocupaçáo da Câmara de Vereadores de Porto Alegre. O nome do grupo ganhou certa repercussão nacional no ano de 2014, quando a banda, que se auto intitula coletivo, fez uma apresentação em programa da TV Educativa do estado do Rio Grande do Sul (TVE-RS). A apresentação se deu no contexto de divulgação da Marcha das Vadias de Porto Alegre e foi precedida por uma entrevista, que foi ao ar às $18 \mathrm{~h} 30$ do dia 24 de abril. Por conta do conteúdo julgado inapropriado, a apresentação na íntegra só foi veiculada na madrugada do dia seguinte, por volta das $02 \mathrm{~h} 30$ da manhã. A performance iniciou com os versos "Se o Papa fosse mulher, o aborto seria legal" $e$ "Ei, Papa, levanta o teu vestido / Quem sabe aí embaixo não está o Amarildo". 23

O vídeo do programa também foi disponibilizado no Youtube e alcançou mais de 500 mil visualizações. Virou assunto na Câmara de Vereadores de Porto Alegre, onde integrantes do Partido Progressista protocolaram um requerimento de moção de repúdio à TVE-RS por ter apresentado o grupo, argumentando que se trata de um vídeo "atentatório à moral $e$ aos bons costumes $e$ ofensivo à figura do Papa Francisco", com "linguajar chulo, de baixo nível" e enviaram uma notificação à banda-coletivo. ${ }^{24}$ Dias depois a emissora demitiu dois funcionários responsáveis por publicar no Youtube o vídeo da apresentação. Em nota no Facebook sobre o ocorrido, a banda contou que integrantes do

\footnotetext{
${ }^{23}$ Amarildo Dias de Souza se tornou símbolo do abuso de autoridade e violência policial por conta do seu "desaparecimento" no ano de 2013, quando foi detido por policiais militares na porta da sua casa, na Favela da Rocinha (Rio de Janeiro), sendo levado em direção à sede da Unidade de Polícia Pacificadora do bairro. Os próprios policiais são os principais suspeitos do seu desaparecimento.

${ }^{24}$ Disponível em: <http:/www.revistaforum.com.br/blog/2014/05/putinhasaborteiras-recebem-notificacao-partido-progressista/> . Acesso em 27 nov. 2015.
} 
coletivo foram expostas, e tiveram sua integridade física e mesmo suas famílias ameaçadas. ${ }^{25}$

Feita a digressão sobre as Putinhas Aborteiras, após ler a nota sobre a agressão policial me dirigi até a praça onde a Feira acontecia. Nesse momento, notei a presença de pessoas e atores políticos discrepantes, tais como homens e mulheres mais velhas $e$ militantes partidários. Estavam sentados no chão da praça, em uma roda de conversa com cerca de sessenta pessoas quantidade que cresceu ao longo do dia, o qual terminou com a realização de uma caminhada pelo centro da cidade em protesto contra a agressão policial, contando com mais de 300 participantes. ${ }^{26}$

$\mathrm{Na}$ roda de conversa, pessoas diversas pediam a fala. Entre elas, um homem que se apresentou como docente da UFRGS (Universidade Federal do Rio Grande do Sul) e parecia alguém mais ou menos conhecido naquele meio político da esquerda local. Entre outras coisas, ele defendeu que aquele não era o momento para polarizações entre psolistas e anarcos e que a tarefa então posta consistia em "disputar o fato" da agressão com outros atores, como a mídia.

Surpreendeu-me a presença da parlamentar Maria do Rosário, deputada federal pelo PT-RS (Partido dos Trabalhadores). Ela estava acompanhada por outras mulheres também mais velhas e aguardava em pé numa posição recuada a sua vez de falar. Se colocou à disposição e em solidariedade - em suas palavras, não só como parlamentar mas como pessoa física, e deixou o seu contato. Disse ter recebido uma ligação da ex-ministra Eleonora Menicucci a qual prestava também solidariedade e via a agressão como parte do contexto de recrudescimento do conservadorismo no país. Maria do Rosário em seguida deixou o local, alegando

${ }^{25}$ Disponível

em: $<$ https://www.facebook.com/permalink.php?story_fbid $=764427180266634 \&$ id $=$ $628630013846352>$. Acesso em 27 nov. 2015.

${ }^{26}$ No dia seguinte, 03 de novembro, em Porto Alegre, foi realizado um outro ato, dessa vez impulsionado espontaneamente por outras organizações feministas em solidariedade à FLIFEA. 
que aquele era um movimento autônomo e não cabia a ela continuar ali. Ao sair, foi aplaudida por uma minoria.

Também estavam presentes advogadas de organizações feministas, que se colocaram a disposição para ajudar. A diretora do Conselho Municipal de Direitos da Mulher, uma mulher negra aparentando cerca de 60 anos, fez uma fala que emocionou muitas ali presentes. Enquanto acontecia a assembleia, se aproximou uma repórter da filial da TV Globo do Rio Grande do Sul. Logo; algumas garotas se levantaram, se colocaram rapidamente na sua direção e a abordaram de forma ríspida, para que se retirasse do local - sinalizando os limites das possibilidades de interlocução então abertas.

Entre as mulheres que chamaram a assembleia chegou-se ao consenso de que se tratava de: a) violação aos Direitos Humanos por violência policial; b) censura e criminalização de movimentos sociais; c) violência contra a mulher; d) racismo, pois a abordagem da polícia teve como alvo principal uma das poucas mulheres negras presentes naquele momento do evento, quando se realizava um ensaio de performance que ocorreria no dia seguinte. Também se decidiu pela não realização de ações legais individuais por parte das agredidas.

Uma moradora da região fez o seguinte relato em comentário no Facebook, no qual chama atenção as categorias acusatórias acionadas pelos policiais:

Meus parabéns à Brigada Militar, que mais uma vez demonstrou quem e quais valores representa. Da sacada de casa vi as gurias que confraternizavam na Feira do Livro Feminista serem brutalmente agredidas, a feira foi totalmente "dissolvida". Quando gritei "muito bonito, batendo em mulher" um deles me respondeu "vai à merda, vadia maconheira". É assim que eles reagem ao questionamento, quando quem questiona é uma mulher. Eu estou em casa, vejo da janela três homens agredindo um monte de gurias, grito com eles e ainda sou tenho que ouvir um sonoro "vadia maconheira", e vem me dizer que 
os agressores são os mesmos responsáveis pela minha segurança? Juras. ${ }^{27}$

O modo dramático em que a primeira edição da FLIFEA teve fim merece algumas considerações. A presença de grupo de acolhimento e comissão de segurança internos não é um fato isolado, mas lugar comum em outros eventos do trabalho de campo. Tal como exposto nas regras de convivência fixadas nas pilastras da praça que sediou a Feira, são comissões que devem ser acionadas por participantes a fim de intervir em alguma situação percebida como violenta.

Como uma modalidade de política prefigurativa, a lógica da okupação pressupõe a existência de ameaças externas, quase sempre personificadas em corpos tidos como intrusos e hostis, cuja presença interrompe o andamento do evento e requer reação imediata (o escracho). Por seu turno, essa reação encena uma batalha com "o machismo" personificado no "inimigo" que deve ser expulso para salvaguardar a pretendida suspensão de valores e práticas da sociedade mais ampla. Esses duelos transferem estruturas sociais - como o sexismo - para indivíduos (agressor), e quando transpostos para o âmbito online, são amplificados com rastreio, acesso e exposição de dados pessoais e assédio às ativistas. $^{28}$

${ }^{27}$ Disponível

em:

$<$ https://www.facebook.com/isa.librenza/posts/979606262082970>. Acesso em 26 nov. 2015.

${ }^{28}$ Nos últimos anos, a prática do escracho, tal como apropriada por setores feministas autônomos, tem provocado reações diversas, seja por parte de setores do campo feminista ou fora dele. Carla Gomes e Bila Sorj (2014) trazem uma importante contribuição ao abordar tensões raciais em torno do escracho na Marcha das Vadias de Brasília no ano de 2013. O ocorrido foi filmado e divulgado em redes sociais, gerando grande repercussão e controvérsias. Como descrevem as autoras, "o vídeo mostrava um homem negro, portando muletas, levantando a camisa, tocando seu abdome e seu pênis por cima da bermuda, simulando prazer sexual. Em volta dele, militantes da marcha, mulheres brancas em sua maioria, usavam apitos e buzinas para denunciar a presença de um 'agressor' ou 'machista', como tem sido de praxe em diversas marchas pelo país em situações análogas, e forçar sua saída daquele espaço, o que é chamado de 
Por outro lado, as estratégias ativistas provocativas também merecem consideração, ao serem lidas por outros atores sociais como desordem e bagunça, como evidenciado na categoria acusatória utilizada pelo policial (vadia maconheira) - a qual busca localizar as minas do rolê fora do âmbito legítimo do político. A inversão do lugar de enunciação de termos pejorativos como puta, vadia, sapatão e bruxa, que passam do âmbito da acusação à autonomeação, é parte do uso do humor no formato do deboche e da chacota que rejeitam repertórios no registro da respeitabilidade.

Igualmente chama atenção a presença de agentes como a Deputada Maria do Rosário, militantes partidários e a diretora do Conselho Municipal de Direitos da Mulher, o que revela não só a capacidade do role em mobilizar, em curto espaço de tempo, uma rede mais ampla de apoio, como também sinaliza o que Alvarez et alii (2017) chamam de "Civic-uncivic continuum". Isto é, embora parte da literatura assuma que o atual cenário de mobilizações constitui o "outro" da sociedade civil - a antítese do cívico, das ONGs profissionalizadas e associações de bairro que "escolheram" por entrar nos âmbitos e espaços oficiais de participação criados entre o final dos anos 1980 e a década de 1990 -, um olhar mais detido mostra que as fronteiras entre sociedade civil e seus presumidos "outros" não são precisas, mas objeto de constante negociação. Ao contrário da repórter da Rede Globo, Rosário e

'escracho'. Ao que a edição do vídeo e os comentários indicam, foram vários minutos de barulho ensurdecedor e de assédio fotográfico de jornalistas $e$ participantes sobre o homem. Algumas organizadoras, então, tentam demover as pessoas do escracho e levá-las de volta ao protesto. Enfim, abre-se uma brecha na multidão e o homem se afasta, deixando visivel ao espectador sua perna amputada. Irritado, ele atira sua muleta contra um carro" (Gomes; Sorj, 2014:442). Setores feministas negros, como o portal Blogueiras Feministas, criticaram o episódio com veemência, apontando, no limite, os perigos da ação política baseada em categorias como "agressor". Um texto no site questionava: "[...] Alguém explica isso: como mulheres em grande parte brancas $e$ universitárias, hostilizando e perseguindo um homem negro, pobre, deficiente $e$ com problemas mentais pode ser igual à luta contra o machismo?" (Gomes; Sorj:442). 
demais representantes institucionais tiveram espaço e direito à fala na assembleia, mesmo não compartilhando a mesma visão de mundo do rolê.

\section{Considerações finais}

As situações descritas ocorridas na FLIFEA remetem aos embates nos Encontros Nacionais de Mulheres (ENM) da Argentina advindos da presença de grupos associados à Igreja Católica que advogam uma agenda anti-aborto, lesbofóbica e anti-direitos sexuais e reprodutivos. Além dos conflitos dentro do próprio encontro relacionados à participação deliberada de mulheres organizadas por paróquias locais nos workshops do ENM, atritos usualmente acontecem durante a marcha ao final do Encontro, cujo percurso passa por igrejas que se encontram circundadas por homens fazendo um cordão de isolamento $e$ vocalizando palavras de ordem (Tarducci, 2017).

Segundo Tarducci (2017), nos últimos encontros tem acontecido algo novo. Geralmente, ao passar pelo cordão, as mulheres gritam palavras de ordem anticlericais, denunciando a complacência da Igreja Católica com os crimes da ditadura argentina $e$ a sua posição contra os direitos das mulheres, e então seguem o trajeto da marcha. Recentemente, contudo, uma parte das participantes passou a se manter manifestando-se em frente à igreja, enquanto a grande maioria segue caminhando em direção ao ponto de chegada.

Nos escrachos ${ }^{29}$ na frente das igrejas, essas jovens, de rostos cobertos, exibem seus seios despidos (muitas vezes pintados com símbolos lésbicos e anticlericais), se beijam, simulam atos sexuais, e tocam seus genitais com rosários. Essas ações são filmadas tanto pelos grupos anti-direitos quando por mulheres que participam da

\footnotetext{
${ }^{29}$ Como conta Tarducci (2017:9), originalmente "Escrache' es el nombre con que los hijos de detenidos-desaparecidos durante la dictadura denominan a las denuncias que, a falta de justicia, realizaban en frente de las casas que habitaban militares comprometidos en la violación a los Derechos Humanos".
} 
marcha, sendo que os registros são disponibilizados para acesso em redes sociais.

Há registros de violência contra manifestantes durante esse momento das marchas. Considerando que a maioria das manifestantes não se mantém tanto tempo nesse ritual em frente à igreja e seguem para o destino final, isso faz com que aquelas que aí permanecem fiquem isoladas e passíveis de serem reprimidas por agentes policiais. Os escrachos, ao lado de ações como a pichação de frases em paredes de edifícios públicos e privados e de casas particulares e automóveis durante os ENM têm gerado muita discussão entre as feministas da Argentina. Embora todas condenem a violência policial, parte delas argumentam que essas ações são usadas contra os próprios Encontros e provocam rechaço da população e da mídia, que chamam essas práticas de "vandalismo", "violência" e "vulgaridade".

Assim como o rolê, a atuação dessas ativistas é parte do que Tarducci (2017) nomeia como novas formas de aparição pública dos feminismos. Nesse processo, o corpo é dotado de centralidade - não só como causa ou objeto de reivindicação, mas também como um veículo do protesto (Tarducci, 2017; Carmo, 2016, 2018a; Gomes, 2017), que encarna, vivencia e prefigura aquilo pelo qual se luta. Como as situações etnográficas aqui discutidas mostram, é também ao corpo que se voltam as reações violentas (muitas vezes de forma racializada).

A reivindicação por autonomia e a recusa a formas institucionalizadas de participação em si mesmas não constituem algo inédito, como evidenciam etnografias realizadas no país na década de 1980, como em Gregori (1993) e MacRae (1990). Recentemente, contudo, o termo tem sido manejado de modo a acionar políticas prefigurativas na rede ativista pesquisada, denotando críticas a formas institucionalizadas de participação política.

Como busquei mostrar, a autonomia carrega sentidos prefigurativos que se traduzem na experimentação coletiva de novos códigos e condutas percebida enquanto ato político. $\mathrm{Ou}$ seja, entende-se por autonomia não só a rejeição à interferência 
de instituições, como o Estado, e de organizações, como partidos políticos e sindicatos, mas também a suspensão de valores $e$ convenções da sociedade mais ampla, de modo a ocupar não só a rua, como o corpo e o tempo/espaço, por vezes culminando na prática do escracho - a qual deve ser entendida tendo em vista também os constrangimentos sociais que se somam à experimentação.

$\mathrm{Se}$ as experimentações coletivas prefigurativas tal como ensejadas no rolê são mobilizadas pela noção de autonomia, elas também estão indissociavelmente ligadas à condição de existência de corpos vulneráveis que circulam através do rolê. Entendendo a vulnerabilidade não como uma disposição subjetiva, mas como uma condição socialmente induzida, informada por uma exposição diferencial ao sofrimento e à violência (Butler, 2016, 2017) ${ }^{30}$, é possível compreender essa sociabilidade que produz relações de afinidade e afeto compartilhadas e baseadas em sentimentos de segurança, proteção e aceitação, tão presentes nos discursos das interlocutoras desta pesquisa.

Frequentemente representadas como "não cívicas", tais modalidades de atuação têm ganhado cada vez mais visibilidade no período que sucede os anos 2000 (Alvarez et alii, 2017). Elas coexistem com a consolidação, nas últimas duas décadas, da "participação cívica" através do chamado terceiro setor e dos espaços de interlocução socioestatais, nos quais está ancorada a noção de sociedade civil. ${ }^{31}$

\footnotetext{
${ }^{30} \mathrm{~A}$ exposição diferencial à violência se desdobra a partir de uma distribuição desigual da dignidade do luto, isto é, normas que governam a inteligibilidade do corpo, e definem quais vidas contam como válidas de proteção e quais não; estabelecem as "vidas vivíveis", ao regular, classificar, criminalizar e patologizar certos modos de existência corporal (Butler, 2017).

31 Thayer (2017) e Alvarez et alii (2017) discorrem sobre a promoção da linguagem da sociedade civil e da participação cívica na América Latina por parte de atores como governos neoliberais e agência internacionais, frequentemente por intermédio de Organizações Não Governamentais e organizações da sociedade civil. Mais especificamente, Guterres, Vianna e Aguião (2014) apresentam as vicissitudes da participação civil no âmbito da Conselho Nacional
} 
Essas duas dimensões das mobilizações contemporâneas têm sido constantemente tratadas de forma polarizada. Como Alvarez et alii discutem, as fronteiras entre sociedade civil e seus presumidos "outros" não são fixas e estáveis; os movimentos cruzam a divisão cívico-não cívico, transbordam a agenda da sociedade civil e atuam em gray zones - perpassando não só o Estado e suas instituições, como o mercado, a universidade, cenas artísticas e culturais e outros movimentos sociais.

Frente a essas reconfigurações ativistas e mudanças nos processos de engajamento, parte da literatura sublinha os limites da categoria movimento social, em função da rigidez dos pressupostos analíticos que carrega em termos de sujeito, formatos organizativos, modos e lugares de atuação. ${ }^{32}$ Nesse sentido, rolê pode oferecer uma contribuição analítica relevante: carregando sentidos associados a experimentação, trânsito e provisoriedade, ele atravessa os limites semânticos entre sociabilidade e fazer político, lançando luz sobre outras iniciativas ativistas que rejeitam a autonomeação como movimento social (Lima, 2016; Gomes, 2018).

\section{Referências bibliográficas}

AlVAREZ, Sônia. Para além da sociedade civil: reflexões sobre o campo feminista. cadernos pagu (43), Campinas-SP, Núcleo de Estudos de Gênero-Pagu/Unicamp, jan-julho 2014, pp.13-56.

ALVAREZ, Sonia et alii. Introduction: Interrogating the civil society agenda, reassessing uncivic political activism. In: ALVAREZ, Sonia et alii (org.). Beyond civil society: activism, participation, and protest in Latin America. Durham \& London, Duke University Press, 2017, pp.1-24.

dos Direitos da Mulher (CNDM) e da Secretaria de Políticas para as Mulheres (SPM), explorando as experiências das conselheiras.

32 Aqui tenho em mente as críticas tecidas por autoras como Alvarez (2014), Thayer e Rubin (2017), Bringel e Pleyers (2015), entre outras. 
BRINGEL, Breno; PleYERS, Geoffrey. Junho de 2013... dois anos depois: polarização, impactos e reconfiguração do ativismo no Brasil. Nueva Sociedad, vol. 2015, n. 2, 2015, pp. 4-17.

ButLER, Judith. Problemas de gênero: feminismo e subversão da identidade. Rio de Janeiro, Civilização Brasileira, 2003.

BUTLER, Judith. Corpos que pesam: sobre os limites discursivos do "sexo". In: LouRO, Guacira (org.). O corpo educado: pedagogias da sexualidade. Belo Horizonte, Autêntica Editora, 2010, pp.151-172.

ButLER, Judith. Notes toward a performative theory of assembly. Cambridge, Harvard University Press, 2015.

BUTLER, Judith. Rethinking vulnerability and resistance. In: BUTLER, Judith; GAMBETTI, Zeynep; SABSAY, Leticia (org.). Vulnerability in resistance. Durham and London, Duke University Press, 2016, pp.1227.

BUTLER, Judith. Alianças queer e política anti-guerra. Bagoas, n. 16, Natal, RN, UFRN, 2017, pp.29-49.

CALDEIRA, Teresa. Qual a novidade dos rolezinhos? Espaço público, desigualdade e mudança em São Paulo. Novos Estudos, n. 98, São Paulo, CEBRAP, março 2014, pp.13-20.

CARMO, Íris Nery do. "Fiz do meu corpo a revolução": gastropolíticas e contestações de gênero, sexualidade e espécie. In: COLLING, Leandro (org.). Dissidências sexuais e de gênero. Salvador, Edufba, 2016, pp.91-108.

CARMO, Íris Nery do. O perigo das dobras: iconografias e corporalidades no feminismo contemporâneo. Sociologia \& Antropologia. vol. 8, n. 1, 2018a, pp.193-222.

CARMO, Íris Nery do. O rolê feminista: autonomia, horizontalidade e produção de sujeito no campo feminista contemporâneo. Tese (Doutorado em Ciências Sociais) - Instituto de Filosofia e Ciências Humanas, Universidade Estadual de Campinas, Campinas, 2018b.

FACCHINI, Regina; SÍvORI, Horacio. Conservadorismo, direitos, moralidades e violência: situando um conjunto de reflexões. cadernos pagu (50), Campinas-SP, Núcleo de Estudos de Gênero-

Pagu/Unicamp, 2017 
[http://www.scielo.br/scielo.php?script=sci arttext\&pid=S010483332017000200301 - acesso em 2 nov. 2017].

FACCHINI, Regina. RoDRIGUES, Julian. "Que onda é essa?": "guerras culturais" e movimento LGBT no cenário brasileiro contemporâneo. In: VIANA, Frederico Machado (org.). A diversidade e a livre expressão sexual entre as ruas e as políticas públicas. Porto Alegre, Editora Rede Unida; Nuances, 2017, pp.35-60.

FACCHINI, Regina. Entre umas e outras: mulheres, (homo)sexualidades e diferenças na cidade de São Paulo. Tese (Doutorado em Ciências Sociais) - Instituto de Filosofia e Ciências Humanas, Universidade Estadual de Campinas, Campinas, 2008.

FARBER, Samuel. Reflexões sobre a política pré-figurativa. Nueva Sociedad. dez. 2014, pp.76-92 [https://nuso.org/articulo/reflexoessobre-politica-pre-figurativa/ - acesso em 02 nov. 2017].

GOMES, Carla; SoRJ, Bila. Corpo, geração e identidade: a Marcha das Vadias no Brasil. Revista Sociedade e Estado, vol. 29, n. 2, maio/ago. 2014, pp.433-447.

GOMES, Carla de Castro. Corpo e emoção no protesto feminista: a Marcha das Vadias do Rio de Janeiro. Sexualidad, salud y sociedad, n.25, Rio de Janeiro, IMS/UERJ, abril 2017, pp.231-255.

GOMES, Carla de Castro. Corpo, emoção e identidade no campo feminista contemporâneo brasileiro: a Marcha das Vadias do Rio de Janeiro. Tese (Doutorado em Sociologia e Antropologia) - IFCS/ UFRJ, Rio de Janeiro, 2018.

GONÇALVES, Eliane; FREITAS, Fátima; OliveIRA, Elismênia. Das idades transitórias: as "jovens" no feminismo brasileiro contemporâneo, suas ações e seus dilemas. Revista Feminismos, vol. 1, n, 3, set./dez. 2013 [https://portalseer.ufba.br/index.php/feminismos/article/view/29994/17 736 - acesso em 02 nov. 2017].

GREGORI, Maria Filomena. Cenas e queixas: um estudo sobre mulheres, relações violentas e a prática feminista. Rio de Janeiro, Paz e Terra, 1993.

GutTerRES, Anelise; VIANNA, Adriana; Aguião, Silvia. Percursos, tensões $e$ possibilidades da participação de movimentos de mulheres $e$ feminista nas políticas governamentais. In: HEREDIA, Beatriz; LOPES, 
José Sérgio Leite (org.). Movimentos sociais e esfera pública. Rio de Janeiro, CBAE, 2014, pp.211-236.

LimA, Stephanie. "As bi, as gay, as trava, as sapatão tão tudo organizada pra fazer revolução!" Uma análise sócio-antropológica do Encontro Nacional Universitário da Diversidade Sexual (ENUDS). Dissertação (Mestrado em Saúde Coletiva), Universidade do Estado do Rio de Janeiro, Rio de Janeiro, 2016.

MATOS, Marlise. A quarta onda feminista e o campo crítico-emancipatório das diferenças no Brasil: entre a destradicionalização social e o neoconservadorismo político. $38^{\circ}$ Encontro Anual da ANPOCS, Caxambu, 2014.

MACRAE, Edward. A construção da igualdade: identidade sexual e política no Brasil da "Abertura". Editora da Unicamp, Campinas, 1990.

MPL, Movimento Passe Livre. Não começou em Salvador, não vai terminar em São Paulo. In: MARICATO, E. et alii. Cidades Rebeldes. Passe Livre e as manifestações que tomaram as ruas do Brasil. São Paulo, Boitempo, 2013, pp.13-18.

ORTELLADO, Pablo. Os protestos de junho entre o processo e o resultado. In: Vinte centavos. a luta contra o aumento, 2013 [http://www.cartacapital.com.br/sociedade/os-protestos-de-junhoentre-o-processo-e-o-resultado-7745.html - acesso em $05 \mathrm{fev}$. 2016].

ORTIZ, Elaine. Silveira, Sergio. Redes sociais, censura privada e modulação. Anais. $37^{\circ}$ Encontro Anual da ANPOCS. Águas de Lindóia/SP, 23 a 27 de setembro de 2013.

ROLNIK, Raquel. Apresentação - As vozes das ruas: as revoltas de junho e suas interpretações. In: MARICATO, E. et alii. Cidades Rebeldes: Passe Livre e as manifestações que tomaram as ruas do Brasil. São Paulo, Boitempo, 2013, pp.7-12.

TARDUCCI, Monica. "Poner el cuerpo" en las calles: los enfrentamientos de las activistas feministas y los grupos anti-derechos. cadernos pagu (50), Campinas-SP, Núcleo de Estudos de Gênero-Pagu/Unicamp, 2017 [http://www.scielo.br/scielo.php?script $=$ sci arttext\&pid $=$ S0104$83332017000200313 \& \operatorname{lng}=\mathrm{pt \& nrm}=$ iso - acesso em 02 nov. 2017]. 
THAYER, Millie. The "gray zone" between movements and markets: Brazilian feminists and the international Aid Chain. In: ALVAREZ, Sonia et alii. Beyond Civil Society. activism, participation, and protest in Latin America. Durham and London, Duke University Press, 2017, pp.156-176.

THAYER, Millie; RUBIN, Jeffrey. Uncontained activism. In: AlvarEZ, Sonia. et alii (org.). Beyond civil society. activism, participation, and protest in Latin America. Durham \& London, Duke University Press, 2017, pp.331-337.

YATES, Luke. Rethinking prefiguration: Alternatives, micropolitics and goals in social movements. Social Movement Studies, n. 14, vol. 1, 2015, pp.1-21. 